\title{
Essentials of Successful Potato Culture in Puerto Rico
}

\author{
Juan Pastor Rodríguez and Pablo Landrau, Jr. ${ }^{1}$
}

\section{INTRODUCTION}

Several attempts have been made to establish potato culture in Puerto Rico on a commercial scale. Potatoes are not produced to any appreciable extent in the Island, although successful crops have been grown in certain regions of the highlands.

Potatoes constitute an important item in the diet of the Puerto Rican family, especially families of the middle class. Yet the Island depends almost entirely on importations for its supply of this important commodity.

According to the Annual Book of Statistics of the Commonwealth Department of Agriculture and Commerce, the average annual importations of potatoes for the 5-year period 1935-40 was 49,115,815 pounds, valued at $\$ 507,867$. In 1951-52, the importations from the United States and foreign countries amounted to $79,195,000$ pounds, valued at $\$ 1,997,000$.

Of the 55,519 farms operating in Puerto Rico only 496 reported some land devoted to potato production. Of these, 336 farms reported plantings of less than 1 "cuerda."2 Most of the potato production, therefore, is grown in small lots, mainly for home consumption.

Potato production, however, has not generally been profitable in the Island because of the diseases that attack this crop here-early blight (Aternaria solani), late blight (Phytopthora infestans), and bacterial wilt (Pseudomonas solanacearum)-and lack of experience in handling the harvested crop.

The people of Puerto Rico prefer locally grown potatoes, when available, to the imported old-crop potatoes. Consumers are always willing to pay a premium price for the locally grown potatoes. During war periods or stevedore strikes, the importations of potatoes have been almost negligible.

It has been found that good crops of potatoes can be produced in such highland locations as Orocovis, Barranquitas, Cidra, Adjuntas, Aibonito, and Cayey. However, prior to 1943-44, trials were never conducted in the rich coastal-lowland soils where sugarcane is grown under irrigation.

Potatoes have always been regarded by our agronomists as a potential crop to increase the Island sources of food supply. But before any recommendation could be made it was necessary to determine: 1 , The best varieties for the highlands, where it is cooler; 2, the possibilities of growing

1 Associate Agronomists, Agricultural Experiment Station, University of Puerto Rico, Río Piedras, P. R.

2 The Puerto Rican cuerda is equal to 0.9712 acre, or 42,305 square feet. 
these in the lowlands under irrigation; 3 , the degree of resistance to late blight of a number of promising varieties; and 4, proper storage conditions. This paper reports the results of the studies performed in connection with these factors.

\section{PREVIOUS RESEARCH}

In 1929 and 1930, $(5)^{3}$ the varieties Red Bliss Triumph, Irish Cobbler, Green Mountain, Smooth Rural, and Spaulding Rose No. 4, were imported into the Island for experimental purposes.

Satisfactory yields were obtained with some varieties such as the Bliss Triumph and Green Mountain. The tests, however, were not conclusive. Under Puerto Rican conditions these varieties are very susceptible to late blight and to bacterial wilt, and the crop must be cultivated under a wellcontrolled fungicide program.

In 1928-29 and 1929-30 Pedro Osuna and E. Molinary-Salés (6) conducted variety tests with the potato varieties mentioned above. An equal number of variety trials was located on level land in the mountainous regions of the Island and near the seacoast. The crops of the different varieties were harvested in from 74 to 82 days.

Tables 1 and 2 show the yields obtained by Osuna with the varieties Red Bliss, Irish Cobbler, Green Mountain, Smooth Rural, and Spaulding Rose 4.

The crops gave satisfactory results in some locations, but failed in others. Red Bliss Triumph and Irish Cobbler yields were highest. For the 2-year period studied Red Bliss Triumph appeared to be the outstanding variety, but there did not seem to be any statistical difference between the other varieties.

In a commercial planting with the Red Bliss Triumph in Villalba, at 800 feet above sea level, Ferdinand Méndez Roig obtained, in 1929, an average yield of 82 hundredweights of good large potatoes and 20 hundredweights of small potatoes per cuerda.

\section{STUDIES OF THE NEWLY DEVELOPED VARIETIES}

Le Clerge (3) reported that the new varieties of potatoes, Sebago and Red Warba, were resistant to late blight and could be grown in most seasons without spraying. These varieties and some others which had not been tested in Puerto Rico were imported to determine their adaptability.

Work in this connection began in 1943-44; it was conducted by Policarpo González Ríos until October 1, 1945, and then by Ferdinand Rochet, with the occasional collaboration of Félix Aróstegui, until 1947-48. From that date on the work was continued by the senior author of this article with

${ }^{3}$ Numbers in parentheses refer to Literature Cited, p. 170. 
the collaboration of Arturo Riollano, A. Rodríguez Cabrera, José Adsuar, Luis Alvarez García, Lidy López, R. Gandía Caro, and Marcial Rico Ballester.

TABLE 1.-Mean yields of potatoes in hundredweights per acre in 11 trials performed at different locations in 1929 and 1930

\begin{tabular}{|c|c|c|c|c|c|}
\hline \multirow{2}{*}{ Year and location } & \multicolumn{5}{|c|}{ Yields of varieties indicated } \\
\hline & $\begin{array}{l}\text { Red Bliss } \\
\text { Triumphl }\end{array}$ & Irish Cobbler & $\begin{array}{c}\text { Green } \\
\text { Mountain }\end{array}$ & Smooth & $\begin{array}{c}\text { Spaulding } \\
\text { Rose } 4\end{array}$ \\
\hline 1929 & & & & & \\
\hline Cidra................. & 70 & 57 & 68 & 32 & - \\
\hline Comerío $\ldots \ldots \ldots \ldots \ldots$ & 89 & 61 & 65 & 32 & 46 \\
\hline Adjuntas............... & 134 & 121 & 121 & 74 & 一 \\
\hline Do..................... & 89 & 61 & 65 & 31 & 46 \\
\hline Lares................. & 109 & 89 & 107 & 59 & 86 \\
\hline Isabela $\ldots \ldots \ldots \ldots \ldots \ldots$ & 42 & 53 & 58 & 19 & - \\
\hline Average............... & 89 & 74 & 81 & 41 & 59 \\
\hline 1930 & & & & & \\
\hline Cidra............. & 50 & 40 & 19 & 26 & 37 \\
\hline Comerío.......... & 85 & 99 & 50 & 51 & 97 \\
\hline Adjuntas....... & 60 & 59 & 18 & 23 & 43 \\
\hline 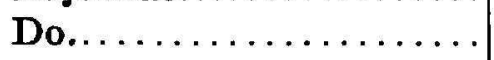 & 50 & 50 & 18 & 38 & 35 \\
\hline Jayuya $\ldots \ldots \ldots \ldots \ldots$ & 95 & 76 & 71 & 43 & 89 \\
\hline Average..... & 68 & 65 & 35 & 36 & 60 \\
\hline
\end{tabular}

TABLE 2.-Average yields and estimated coefficients of variability for the different varieties of potaloes grown during 1929 and 1980

\begin{tabular}{|c|c|c|c|c|}
\hline Variety & 1929 & 1930 & Average & $\begin{array}{l}\text { Estimated } \\
\text { coefficient of } \\
\text { variability }\end{array}$ \\
\hline & Cwol. & Cwt. & Cwt. & Percent \\
\hline Red Bliss Triumph.......... & 80 & 68 & 79 & 5.5 \\
\hline Irish Cobbler.............. & 74 & 65 & 69 & 7.0 \\
\hline Green Mountain............ & 81 & 35 & 58 & 7.2 \\
\hline Smooth Rural. ............. & 41 & 36 & 39 & 8.1 \\
\hline Spaulding Rose $4 \ldots \ldots \ldots \ldots$ & 59 & 60 & 60 & 8.5 \\
\hline
\end{tabular}

The work comprised: 1 , Varietal trials; 2 , the use of fungicidal chemicals; 3 , the use of organic insecticides; 4 , seedling tests; and 5, spacing and fertilizer trials. 


\section{VARIETY TRLALS}

Such potato varieties as Katahdin, Sebago, Green Mountain, Red Bliss, Red Warba, Irish Cobbler, Placid, Virgil, Essex, and Kennebec were tested with and without irrigation in the highlands and in the lowlands.

Regions above 1,500 feet elevation above sea level were considered highlands and lower elevations were regarded as lowlands. The varieties were treated with fungicidal chemicals for the control of both early and late

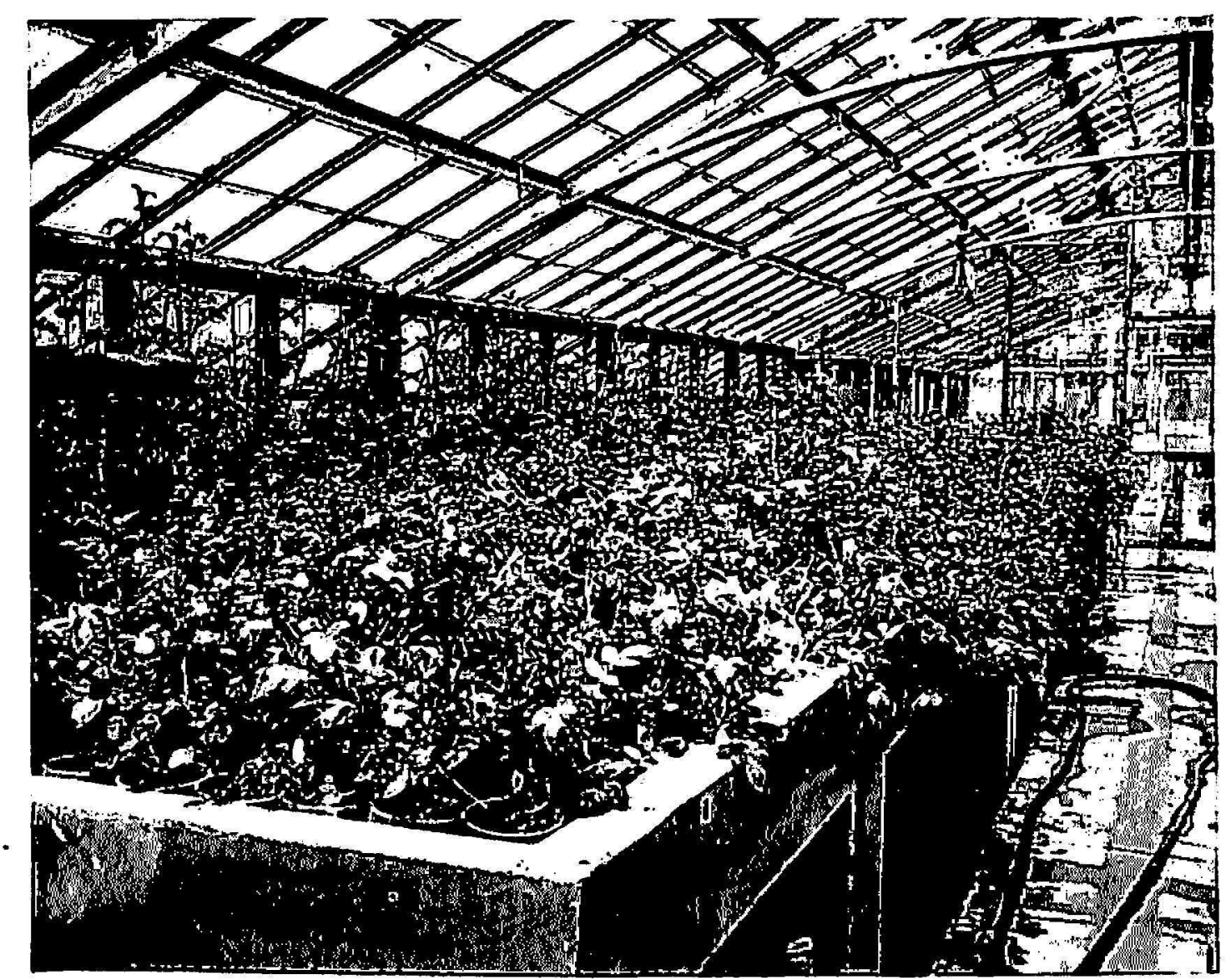

FIG. 1.-Potato seedlings growing in boxes in the greenhouse.

blight, and also with the new organic insecticides for the control of aphids and other potato insects.

In the mountainous regions the sites selected were located at Orocovis, Adjuntas, Cidra, Corozal, and Aibonito. In the lowlands sites were selected at Río Piedras, Isabela, and Colonia Fortuna of the South Puerto Rico Sugar Co.

Tests of adaptability were carried out in collaboration with F. J. Stevenson, Principal Geneticist of U. S. Department of Agriculture at Beltsville, Md. Seedlings bred at Beltsville were sent to us by Dr. Stevenson to be tested under conditions here. These seedlings with "wild blood" in them (Solanum demissum, highly resistant or inmune to blight, and S. poly- 
adenium, a tuberous Mexican species with good vigor inmune to blight), were supposed to be resistant to the early and late blight diseases.

The seedlings were started in boxes made ad hoc in the greenhouse (fig. 1) and were later transferred to the field. It seems that the organism causing the potato blight in Puerto Rico is more active or virulent than the ones to which these varieties are resistant, as most of the seedlings received were severely affected by the blights. To test the resistance of these seedlings to the blight organisms, they were not sprayed with any of the fungicidal chemicals. Such insecticides as DDT and nicotine sulfate were used to keep the potato seedlings free of aphids and of some of the insects that attack potatoes.

In January 1950, Dr. Stevenson sent seed tubers of seedlings identified as Kennebec, Huinkul, B. 75-4, and 46952. Of these, Kennebec has proved to be outstanding in resistance to blight and adaptability to Island conditions. Five hundred pounds of certified-seed tubers were imported from Maine for regional tests at Aibonito on upland soils, and at Isabela on the lowland. These plantings were treated in the same way as any commercial planting, with the exception of spraying for fungus diseases. The test at Isabela had irrigation water when needed, but the one at Aibonito depended on rainfall exclusively.

The following fungicidal chemicals were tried:

Trade name

Active ingredient

Bordeaux Mixture................ Basic copper sulfate

Copper A Compound................. Copper oxychloride

Dithane $\mathrm{D}-14 \ldots \ldots \ldots \ldots \ldots \ldots \ldots \ldots \ldots \ldots \ldots$ Disodium ethylene bisdithiocarbamate

Dithane Z-78...................Zinc ethylene bisdithiocarbamate

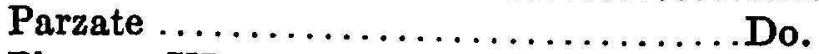

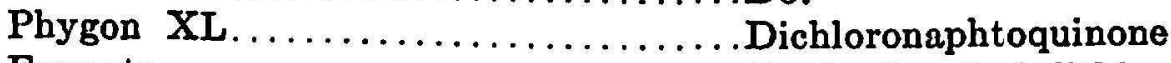

Fermate............................ Ferric dimethyl dithiocarbamate

Zerlate ............................ dinc dimethyl dithiocarbamate

The above chemicals (1) were, in general, solids insoluble in water, but they were readily suspended in water by the use of wettable agents. To avoid drifting of the chemicals from one plot to the other small handsprayers of the Vermorell type were used and spraying was accomplished when the wind was at a minimum. Weekly sprayings were made at all locations. The spraying was started as soon as the seed germinated and the first leaves showed above the soil, and continued until the crop was mature. Before harvesting the crop, the potato plants were sprayed with a solution of $\mathrm{CuSO}_{4}$ in order to kill the mycelia and spores of the pathogen in the soil and in the aerial part of the plants, and thus avoid the contamination of the potato tubers while digging them out, as some of the harvested tubers were to be stored and kept for future plantings. 


\section{FERTILIZER-SPACING}

When the new potato variety Kennebec became available combined fertilizer (2) and spacing experiments were conducted with it at Aibonito (2,000 feet above sea level), Isabela ( 275 feet above sea level), and Corozal (400 feet above sea level).

Five different spacings $(6,9,12,15$, and 18 inches between plants in the row) and varying quantities (2) of nitrogen $(\mathrm{N})$, phosphoric acid $\left(\mathrm{P}_{2} \mathrm{O}_{6}\right)$, and potash $\left(\mathrm{K}_{2} \mathrm{O}\right)$ were tried.

TABLE 3.-Effects of fungicidal treatments to control early blight (Alternaria solani) in the Red Bliss Triumph potato grown at Cidra during the

planting season Feb. 2-May 12,1949

\begin{tabular}{|c|c|c|}
\hline \multirow{2}{*}{ Fungicide used } & \multicolumn{2}{|c|}{ Mean yield in hundredweights per acre of potatoes, by size } \\
\hline & Large potatoes & Large plus small potatoes \\
\hline 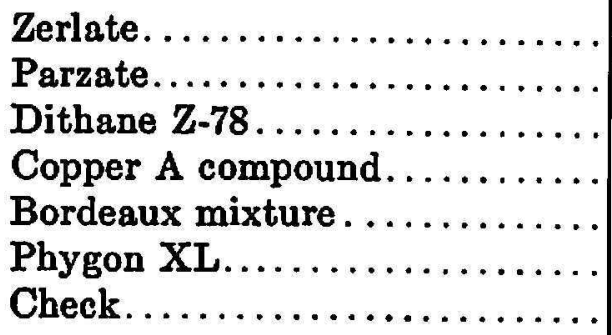 & $\begin{array}{l}80 \\
72 \\
72 \\
68 \\
68 \\
67 \\
61\end{array}$ & $\begin{array}{l}95 \\
89 \\
86 \\
82 \\
84 \\
82 \\
76\end{array}$ \\
\hline
\end{tabular}

Least significant differences at:

5-percent level-10.50

1-percent level-14.14

\section{EXPERIMENTAL RESULTS}

\section{VARIETY TRIAIS}

Decidedly the best time of the year to plant potatoes in Puerto Rico is early in winter. Then good yields were obtained at Orocovis, above 2,000 feet in elevation in the central part; and at Isabela, at 275 feet elevation, in the northwestern side of the Island. During the hot days of summer and autumn the yields were very low.

Despite the differences in climate the varieties showed a better adaptation to the conditions at Isabela (tables 3-9) in the coastal plain than at other locations at higher elevations. At this location the soil was of a much better texture for the production of potatoes and also had irrigation water when necessary. Here (winter season, 1946, table 3) the varieties Sebago, Green Mountain, Irish Cobbler, Red Bliss, and Essex had an average yield of 100 hundredweights per acre of No. 1 potatoes, Green Mountain and Sebago being the outstanding varieties. Aided by the frequent spraying, Red Bliss gave fairly high yields, notwithstanding its 
high susceptibility to blight. In a commercial planting, the variety Kennebec yielded over 150 hundredweights per acre at Aibonito in the mountainous region, and at Isabela in the lowlands near the sea coast.

TABLE 4.-Effects of fungicidal treatments to control early blight (Alternia solani) in the varieties Red Bliss Triumph and Irish Cobbler potatoes grown at Rio Piedras during the planting season December 29-April 8, 1949

\begin{tabular}{|c|c|c|}
\hline \multirow{2}{*}{ Fungicide used } & \multicolumn{2}{|c|}{ Mean yield in hundredweights per acre of potatoes for- } \\
\hline & Red Bliss Triumph & Irish Cobbler \\
\hline Zerlate............. & 43 & 60 \\
\hline Dithane Z-78.......... & 40 & 59 \\
\hline Parzate........... & 38 & 56 \\
\hline Bordeaux mixture.... & 36 & 44 \\
\hline Copper A Compound.... & 41 & 51 \\
\hline Check............... & 37 & 58 \\
\hline
\end{tabular}

Least significant differences at:

5-percent level..........

1-percent level...........

3.86

4.17

5.17

6.30

TABLE 5.-Mean yields in hundredweights per acre of different potato varieties tested at different locations and elevations in the Island during the spring months of 1944 and winter of 1946

\begin{tabular}{|c|c|c|c|c|c|c|c|}
\hline \multirow[b]{2}{*}{ Variety } & \multicolumn{4}{|c|}{ Spring season 1944-45 } & \multicolumn{3}{|c|}{ Winter season $1946-47$} \\
\hline & $\begin{array}{c}\text { Rio } \\
\text { Piedras, } \\
\text { below } \\
1,500 \text { ft. }\end{array}$ & $\begin{array}{c}\text { Isabela, } \\
\text { below } \\
1,500 \mathrm{ft} .\end{array}$ & $\begin{array}{l}\text { Ponce, } \\
\text { below } \\
1,500 \mathrm{ft} .\end{array}$ & $\begin{array}{l}\text { Orocovis, } \\
\text { above } \\
1,500 \mathrm{ft} .\end{array}$ & $\begin{array}{c}\text { Rio } \\
\text { Piedras, } \\
\text { below } \\
1,500 \mathrm{ft} .\end{array}$ & $\begin{array}{l}\text { Isabela, } \\
\text { below } \\
1,500 \mathrm{ft} .\end{array}$ & $\begin{array}{c}\text { Corozal, } \\
\text { below } \\
1,500 \mathrm{ft} .\end{array}$ \\
\hline Katahdin. & 29 & 83 & 31 & 12 & - & 一 & 一 \\
\hline Sebago.... & 20 & 81 & 20 & 7 & 52 & 130 & 35 \\
\hline Green Mountain & 21 & 90 & 27 & 17 & 51 & 126 & 44 \\
\hline Red Warba. . & 25 & 43 & 15 & 19 & - & 一 & - \\
\hline Irish Cobbler. & 25 & 77 & 25 & 20 & 40 & 114 & 29 \\
\hline Red Bliss..... & - & - & - & - & 58 & 102 & 46 \\
\hline Placid........ & - & - & - & - & 42 & 85 & 47 \\
\hline Essex.......... & - & - & - & - & 68 & 110 & 43 \\
\hline
\end{tabular}

Least significant differences needed for comparison between any two means at:
5-percent level ... 6.1
11.9
7.3
8.4
3.8
9.6
3.0
1-percent level... 8.3
15.9
9.8
11.3
5.1
8.9
4.0

\section{FUNGICIDAL CHEMICALS}

Zerlate seemed to be the best fungicide for the control of early blight (Alternaria solani) at Río Piedras and at Cidras, (tables 3-4). As for late blight, (table 9) Copper A Compound, Bordeaux Mixture, and Dithane 
TABLE 6.-The effect of Bordeaux Mixture and Dithane for the control of blights, as indicated by yields in hundredweights per acre of different potato varieties tested during the winter, summer, and autumn of 1945-56 at various locations in the Island

\begin{tabular}{|c|c|c|c|c|c|c|c|c|c|c|c|c|}
\hline \multirow[b]{3}{*}{ Variety } & \multicolumn{4}{|c|}{ Isabela } & \multirow{3}{*}{ 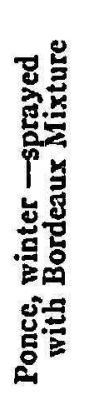 } & \multirow{3}{*}{ 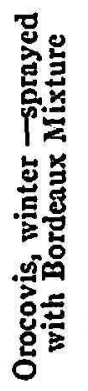 } & \multirow{3}{*}{ 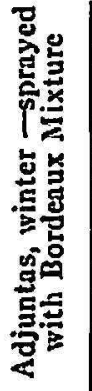 } & \multicolumn{5}{|c|}{ Rfo Piedras } \\
\hline & \multicolumn{2}{|c|}{ Winter } & \multicolumn{2}{|c|}{ Summer } & & & & \multicolumn{2}{|c|}{ Summer } & \multicolumn{3}{|c|}{ Autumn } \\
\hline & 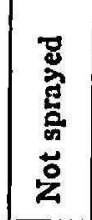 & 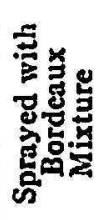 & 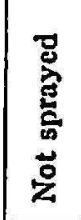 & 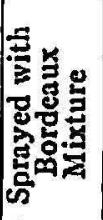 & & & & 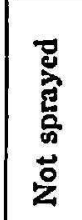 & 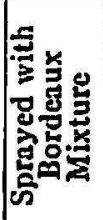 & 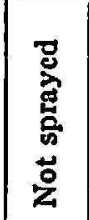 & 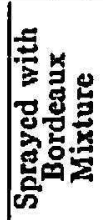 & 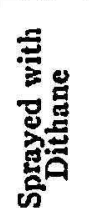 \\
\hline Katahdin. & 47 & 74 & 22 & 43 & 25 & 61 & 29 & 8 & 6 & 21 & 23 & 19 \\
\hline Sebago. . & 53 & 80 & 24 & 33 & 29 & 78 & 46 & 7 & 5 & 26 & 21 & 16 \\
\hline Green Mountain. & 65 & 107 & 41 & 42 & 36 & 85 & 39 & 5 & 6 & 17 & 15 & 15 \\
\hline Irish Cobbler. . & 56 & 102 & 36 & 56 & 23 & 80 & 39 & 4 & 4 & 6 & 6 & 3 \\
\hline Red Bliss... & 77 & 127 & 32 & 30 & 28 & 74 & 59 & .49 & .71 & 20 & 26 & 18 \\
\hline $\begin{array}{l}\text { L.S.D. at the: } \\
\text { 5-percent point. }\end{array}$ & 8.6 & 9.9 & 6.7 & 13.8 & 12.3 & 11 & 9.8 & 2.7 & 2.4 & 6.0 & 6.0 & 6.0 \\
\hline 1-percent point. & 11.6 & 13.1 & 9.1 & 18.6 & 16.6 & 14.9 & 13.2 & 3.6 & 3.2 & 8.0 & 8.0 & 8.0 \\
\hline
\end{tabular}

TABLE 7.-Influence of spacing and major-element fertilizers applied at different rates on the yields in hundredweight per acre of potatoes

in the Isabela, Aibonito, and Corozal trials

\begin{tabular}{r|r|r|r|r|c}
\hline \multicolumn{2}{c|}{ Pounds per acre of } & \multicolumn{3}{|c}{ Mean yields at- } \\
\hline $\mathrm{N}$ & $\mathrm{P}_{2} \mathrm{O}_{3}$ & $\mathrm{~K}_{2} \mathrm{O}$ & Isabela & Aibonito & Corozal \\
\cline { 2 - 6 } & 100 & 100 & 135 & 51 & 54 \\
100 & 0 & 100 & 103 & 49 & 43 \\
100 & 100 & 0 & 147 & 58 & 58 \\
100 & 100 & 100 & 167 & 56 & 66 \\
150 & 150 & 150 & 148 & 56 & 64 \\
200 & 200 & 200 & 146 & 55 & 61 \\
\hline
\end{tabular}

Least significant differences between any 2 general means of fertilizer treatments at:

5-percent level.

24.0

5.3

13.4

1-percent level.

31.7

7.0

17.8

Z-78 proved to be equally effective to check late blight in a highly significant way.

The effect of a fungicide for blight control was very well shown in the Isabela trial 3 (table 5), where potato varieties Katahdin, Sebago, Green Mountain, Irish Cobbler, and Red Bliss sprayed with Bordeaux Mixture 
TABLE 8.-Influence of spacing and major-element ferlilizers applied at difference rates per acre on yields in hundredweights per acre of potatoes in the Isabela, Aibonito, and Corozal trials

\begin{tabular}{c|c|c|c}
\hline \multirow{2}{*}{$\begin{array}{c}\text { Spacing between plants } \\
\text { in the row (inches) }\end{array}$} & \multicolumn{2}{|c}{ Mean yields of potatoes per acre for spacings indicated at- } \\
\cline { 2 - 4 } & Isabela & Aibonito & Corozal \\
\hline & Cwl. & Cwl. & Cwt. \\
6 & 169 & 74 & 71 \\
9 & 154 & 61 & 56 \\
12 & 145 & 54 & 57 \\
15 & 127 & 43 & 54 \\
18 & 111 & 38 & 49 \\
\hline
\end{tabular}

L.S.D. between :

Any 2 general means of spacing treatments at the:

5 -percent level..... $23.2 \quad 7.5$

1 -percent level..... $32.5 \quad 10.5$

TABLE 9.-Effects of different fungicidal chemicals used for the control of late blight

(Phytophthora infestans) on the yield in hundredweights per acre of the potato variety Red Bliss Triumph at Corozal, 1950-51

\begin{tabular}{|c|c|c|c|}
\hline \multirow{2}{*}{ Fungicide tested } & \multicolumn{3}{|c|}{ Mean yield of potatoes per acre, by size } \\
\hline & Large and small, 1950 & Large, 1951 & Large and small, 195 \\
\hline 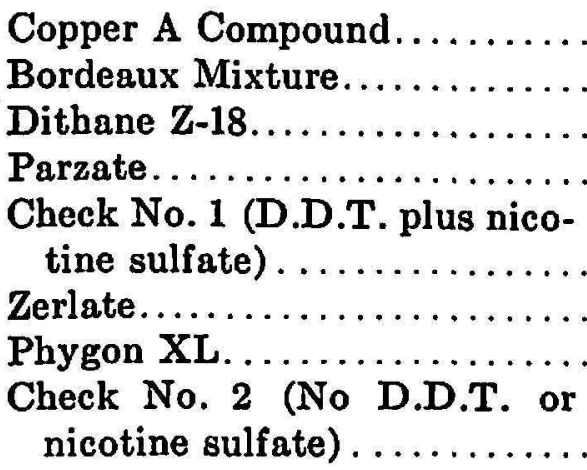 & $\begin{array}{l}83 \\
74 \\
72 \\
54 \\
\\
48 \\
42 \\
35 \\
\\
34\end{array}$ & $\begin{array}{l}43 \\
45 \\
37 \\
34 \\
\\
26 \\
33 \\
39 \\
\\
23\end{array}$ & $\begin{array}{l}63 \\
67 \\
58 \\
56 \\
\\
47 \\
50 \\
60 \\
\\
47\end{array}$ \\
\hline
\end{tabular}

Least significant difference needed for comparison between any two means at:

5-percent level........... 16.6

13.8

15.8

1-percent level............ 22.4

18.6

21.1

produced increases of $26,27,41,44$, and 50 hundredweights, respectively, over the yields of the same varieties unsprayed.

\section{COMBINED FERTILIZER AND SPACING TRIALS}

Of the nutritive elements tried, phosphorus (table 5) proved to be the most limiting for potato production. The results were surprising and far superior at Isabela than at the other locations. Here, on a Coto clay soil, 
with artificial irrigation, the potatoes made better use of the NPK combination than on the heavier Lares and Juncos clay of Corozal and Aibonito.

Some places the soils where the trials were located were suitable for growing potatoes, the preparation of the soil being relatively easy. In other localities the soil used were heavy and needed much plowing and harrowing before a suitable tilth was obtained. At Río Piedras, for example, the experiments were established on a Vega Baja silty clay (4), a moderately acid soil which occurs in a number of widely separated parts of the humid sections of the Island, where it occupies bordering areas between the alluvial and the coastal-plain soils. The soil of the sites chosen for the Isabela experiments was a Coto clay, an acid lateritic soil which occurs in nearly level areas derived from limestone of the tertiary formations. The experiment at Cidra was conducted on a Catalina clay, an acid, red, friable clay soil derived from andesitic tuffs and tuffaceous shales, prevailing in areas receiving more than 79 inches of average annual rainfall. This is the most extensive all-around farming soil of the uplands. The Corozal and the Orocovis experiments were planted on a Lares clay, a lateritic clay ( $\mathrm{pH} 4.5$ ) of the terrace and alluvial fans of Puerto Rico, cropped mainly to sugarcane and pineapples. The experiment at Colonia Fortuna at Ponce was planted on a San Antón silty clay, an alluvial soil located along the southern coast paralleling the streams but at a considerable distance from the riverbanks. The Aibonito experiments were established on a Juncos clay, an acid soil (pH 5.5) of the foothills that occurs in association with the extensive Múcara soils of the mountain areas of the Island and also in association with the soils of the valleys.

The planting distances for these trials varied from 12 to 18 inches between plants in the rows and from 24 and 36 inches between rows. In the fertilizer-spacing trial the spaces between plants were $6,9,12,15$, and 18 inches.

\section{USE OF FUNGICIDAL CHEMICALS}

The varieties under test were sprayed with different fungicidal chemicals to determine their effects on the yield of potatoes. In some instances checks were introduced with and without organic insecticides being used to control the aphids and other insects which are the vectors of the mosaic disease.

\section{SUMMARY}

Potatoes constitute an important item in the diet of the Puerto Rican family. Large amounts of this important commodity are imported to the Island every year, and for this reason it has always been regarded by our agronomists as a potential crop to increase the Island sources of food supply. 
But, before it could become an established crop in Puerto Rico, the optimum conditions in other respects than varieties had to be determined.

Potato trials were conducted under different conditions of soil and climate to find the best way to manage the different factors which are essentials for the successful production of potatoes in the Island.

1. The use of fungicidal chemicals for the control of early and late blights demonstrated that when properly used, such fungicides as Zerlate and Parzate are effective for the control of early blight, and that Copper A Compound, Bordeaux Mixture, and Dithane Z-78 are equally effective to check late blight.

2. Variety trials were conducted at different places in the highlands and lowlands with the commercial varieties Katahdin, Sebago, Green Mountain, Red Warba, Irish Cobbler, Red Bliss, Placid, Essex, and Kennebec. The high-yielding potato variety Kennebec proved to be highly resistant to blights, and gave good yields. Good production could be obtained also with the other varieties mentioned above if blight was fully controlled.

3. Better yields were obtained when the varieties were planted early in the winter season than when they were planted in the summer season.

4. The best yields were obtained when the potatoes were spaced 6 to 9 inches between plants in rows spaced 24 to 30 inches apart.

5. Phosphorous was the most essential fertilizer element to increase the potato yields under the conditions of the trials conducted.

6. Winter appeared to be the best time of the year for the planting of potatoes.

Here also over 150 hundredweights of large potatoes were obtained when the potatoes were spaced 6 and 9 inches between plants (table 6) in the row. The potatoes grown at Isabela were twice the size of those from Aibonito and Corozal (figs. 2 and 3) a great many of them weighing over 12 ounces. At Aibonito and Corozal, where we had to depend on rainwater for the potatoes to grow, the rainfall was rather scanty during the growth period, thus limiting the yields considerably.

The work with distance between plants (table 6) showed great differences in yield of potatoes. The highest yields were obtained when the potatoes were spaced 6 inches between plants in the row.

The yields in the spacing-fertilizer trial (table 7 ) were affected by the climate. In Aibonito, because of abnormal rainy conditions, the seed had to be planted late, hence the sprouted seed tubers had to be kept for a longer time in the barn.

At Corozal the conditions were fairly good at time of planting, but a long drought during the growing period adversely affected the production. At Isabela, production was much better in a looser soil, where a more 


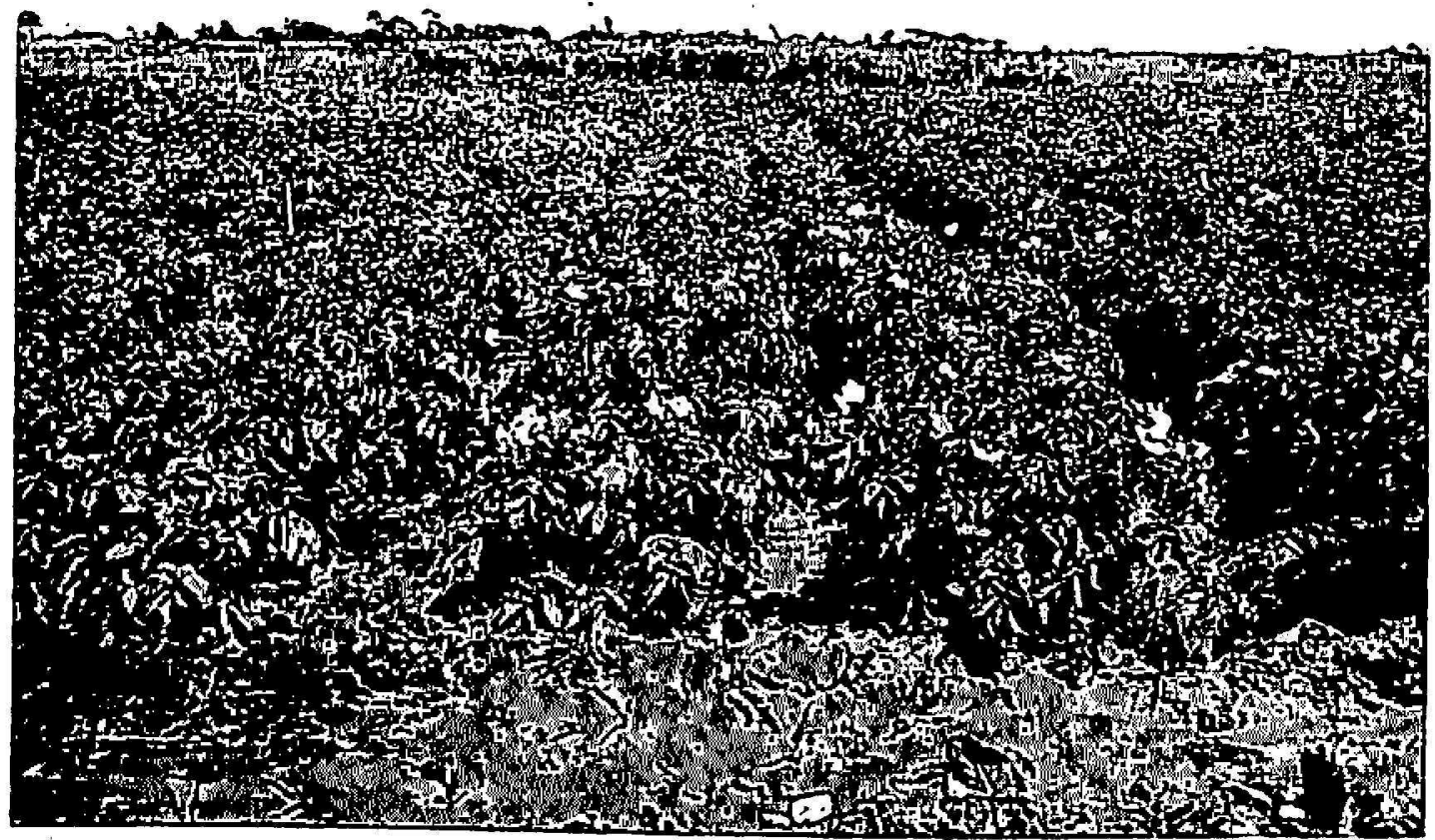

Fia. 2.-Potato variety trial at Isabela Substation. The foreground plants in bloom belong to the Kennebec variety.

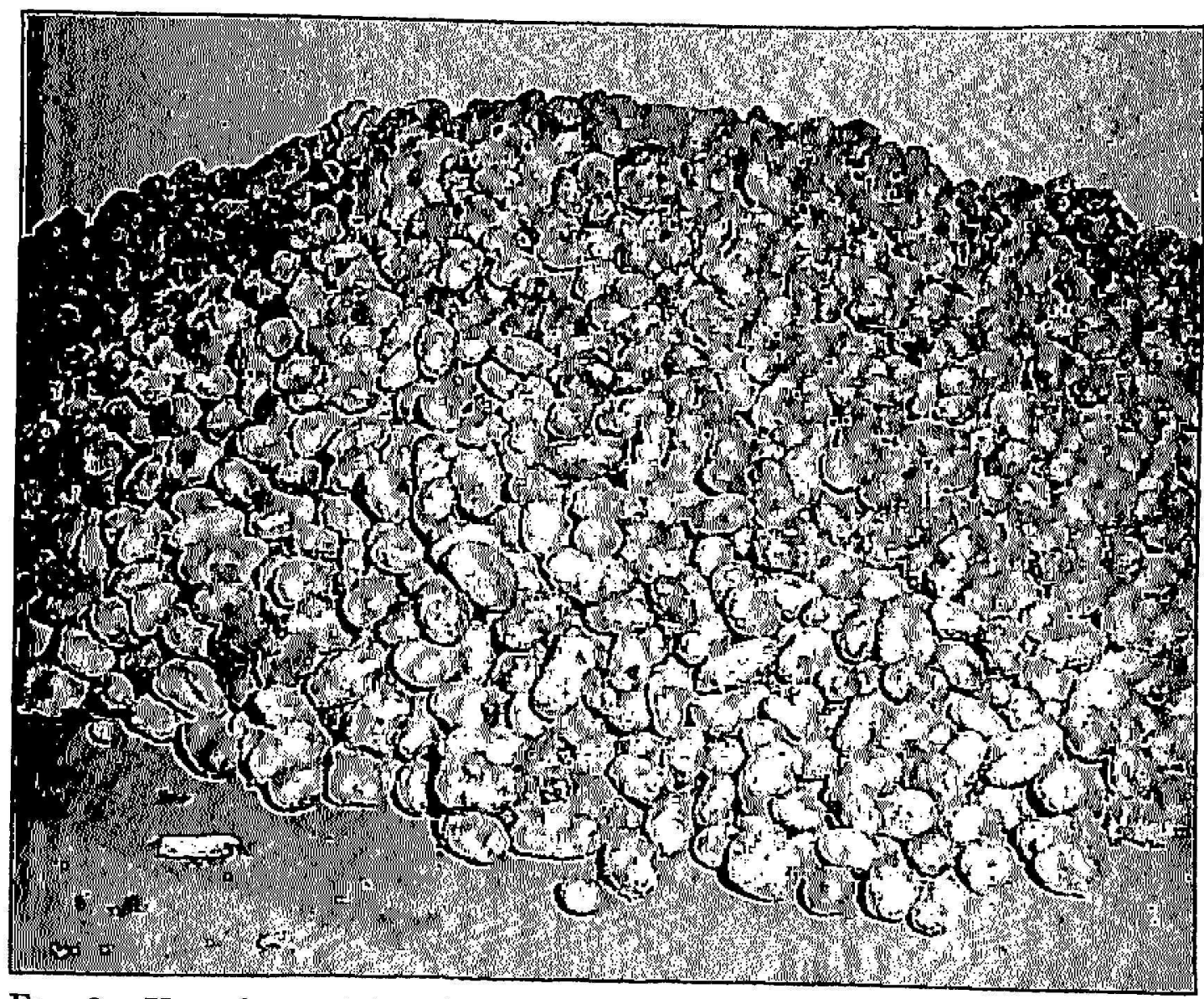

FIG. 3.- Kennebec potatoes in the field immediately after harvesting and before classification at the Isabela Substation. 
favorable climate prevailed during the growth period. Here also there was sufficient irrigation water.

A highly significant correlation was obtained between number of potato seed pieces planted per acre and yield in the experiments at the different locations.

It seems that under normal climatic conditions and with good management and fertilizer practices the variety Kennebec will yield reasonable crops of good No. 1 potatoes when plants are spaced 6 to 9 inches apart in the row (table 6).

It is well to say here that the potato demands a good loose texture in the seedbed and sufficient moisture in the soil for maximum production. In Puerto Rico some of the soils used in the research work with potatoes were heavy and needed much plowing and harrowing. Where a good loose seedbed could not be obtained and the rainfall was scanty the potatoes did not grow well and the yields were very low.

\section{RESUMEN}

La papa es un alimento de gran importancia en la dieta de una buena parte de la familia puertorriqueña, la clase media. Todos los años se importan al país grandes cantidades de papa y por esta razón este producto ha sido siempre considerado por nuestros agrónomos como una cosecha de gran valor potencial. Su siembra en escala comercial no hay duda que aumentaría en la Isla el tan necesario abastecimiento continuo de alimentos. Pero antes de que su cultivo pudiera establecerse en Puerto Rico se necesitaba determinar las condiciones óptimas ambientales para su mejor desarrollo, como también saber cuáles son las mejores variedades adaptables a la Isla.

Se llevaron a cabo distintos experimentos bajo diferentes condiciones de suelo y clima con el propósito de resolver diferentes problemas de campo y ver cuáles son los factores que limitan el éxito de la producción de la papa en la Isla.

Los resultados de estos experimentos indicaron lo siguiente: 1-La aplicación de fungicidas para controlar los tizones tempraneros y tardíos demostró que el Zerlato y el Parzato son eficaces para controlar el tizón tempranero. El Compuesto A de cobre, el caldo bordelés y el Ditano Z-78 dan iguales resultados en cuanto al tizón tardío.

2-En distintos sitios de la altura y la bajura de Puerto Rico se llevaron a cabo ensayos con las variedades Katahdin, Sebago, Green Mountain, Red Warba, Irish Cobbler, Red Bliss Placid, Essex, y Kennebec. Esta última variedad fué más resistente al ataque del tizón y produjo buenas cosechas tanto en la altura como en la bajura. También se lograron buenas cosechas de las otras variedades arriba mencionadas cuando se pudo con- 
trolar totalmente el tizón. De estas variedades las Green Mountain, Katahdin, Sebago y Essex dieron los mejores rendimientos.

3-La producción mayor se logró de las siembras hechas durante el principio del invierno.

4-Todas las variedades produjeron más cuando la semilla se sembró de 6 a 9 pulgadas de distancia en los surcos y de 24 a 30 pulgadas entre surcos.

5-El fósforo fué el elemento fertilizante más esencial para aumentar los rendimientos, bajo las condiciones en que se llevaron a cabo estos experimentos.

6-El invierno parece ser la mejor estación del año para la siembra de la papa en Puerto Rico.

\section{LITERATURE CITED}

1. Alvarez Garcia, Luis A., et al., Fungicidal control of early and late blight of the potato in Puerto Rico, J. Agr. Univ. P. R. 37 (4) 288-97, 1953.

2. Landrau Jr., Pablo, et al., Effect of spacing and fertilization on the yield of potatoes, J. Agr. Univ. P. R. 39 (2) 100-10, 1955.

3. Le Clerge, H. L., Performance of Irish potato varieties in Louisiana, La. Exp. Station Bul. 359, 1943.

4. Roberts, R. C., Soil survey of Puerto Rico U. S. D. A. Bureau of Plant Industry, in cooperation with Univ. of P. R. Agr. Exp. Station, Series 1936, No. 8, 1942.

5. Osuna, Pedro, and Molinary-Salés, E., Hort. Ins. Esp. Station, Annual Report 1928-29, Río Piedras, P. R.

6. - Hort. Ins. Exp. Station, Rio Piedras, P. R., Sept. 1930. 